\title{
Gas phase atmospheric bromine photochemistry
}

\author{
D. J. Lary \\ Centre for Atmospheric Science, Cambridge University, Cambridge, England
}

Abstract. This paper reviews the current knowledge of gas phase bromine photochemistry and presents a budget study of atmospheric bromine species. The effectiveness of the ozone catalytic loss cycles involving bromine is quantified by considering their chain length and effectiveness. The chain effectiveness is a new variable defined as the chain length multiplied by the rate of the cycle's rate-limiting step. The chain effectiveness enables a fair comparison of different catalytic cycles involving species which have very different concentrations. This analysis clearly shows that below $25 \mathrm{~km}$ the $\mathrm{BrO} / \mathrm{ClO}$ and $\mathrm{BrO} / \mathrm{HO}_{2}$ cycles are among the most important ozone destruction cycles.

\section{Introduction}

This paper is a review of gas phase bromine photochemistry and is intended to complement the companion paper [Lary et al. this issue] which considers heterogeneous bromine photochemistry. Bromine enters the atmosphere by a variety of natural and anthropogenic processes. The three main bromine source gases that can reach the stratosphere (i.e. are not removed from the troposphere by rainout, reaction with $\mathrm{OH}$ or photolysis) are $\mathrm{CH}_{3} \mathrm{Br}, \mathrm{CBrClF}_{2}$ and $\mathrm{CBrF}_{3}$. The most abundant of these source gases is methyl bromide $\left(\mathrm{CH}_{3} \mathrm{Br}\right)$ whose natural source is mainly due to oceanic biological processes. In these, mainly algal, processes $\mathrm{CH}_{3} \mathrm{Br}$ is formed together with other species such as $\mathrm{CH}_{2} \mathrm{Br}_{2}$, $\mathrm{CHBr}_{3}, \mathrm{CH}_{2} \mathrm{BrCl}$ and $\mathrm{CHBrCl}_{2}$. The oceans are a significant natural source of $\mathrm{CH}_{3} \mathrm{Br}$ [Singh et al., 1983]. Measurements of larger tropospheric northern hemisphere mixing ratios suggest a large land based northern hemisphere source of $\mathrm{CH}_{3} \mathrm{Br}$ which could well be anthropogenic [Penkett et al., 1985; Reeves and Penkett, 1993]. The main industrial use of $\mathrm{CH}_{3} \mathrm{Br}$ is as a fumigant, particularly for the treatment of soils. $\mathrm{CH}_{3} \mathrm{Br}$ is also used in quarantine treatments and in insect and rodent control.

The wide variety of $\mathrm{CH}_{3} \mathrm{Br}$ measurements made over the last decade in different parts of the world [Berg et al., 1984; Rasmussen and Khalil, 1984; Penkett et al., 1985; Cicerone et al., 1988; Fabian et al., 1994; Kaye et al., 1994] suggest that the natural background concentration of $\mathrm{CH}_{3} \mathrm{Br}$ in the troposphere is approximately 10 pptv. $\mathrm{CH}_{3} \mathrm{Br}$ concentrations of up to $15 \mathrm{pptv}$ have also been observed; these are likely to reflect the effect of anthropogenic sources.

Copyright 1996 by the American Geophysical Union.

Paper number 95JD02463.

0148-0227/96/95JD-02463\$05.00
The first study of atmospheric bromine chemistry was by Yung et al. [1980], who pointed to the general importance of atmospheric bromine chemistry and to the catalytic destruction of ozone by the $\mathrm{ClO} / \mathrm{BrO}$ cycle. Bromine has been shown to play a significant role $(\approx 20 \%)$ in the formation of the ozone hole in polar stratospheric regions [McElroy et al., 1986]. The contributions to ozone loss from bromine reactions are largest below about $20 \mathrm{~km}$ [e.g., Poulet et al., 1992; Garcia and Solomon, 1994]. Bromine plays an important role in stratospheric ozone depletion despite being much less abundant than chlorine [World Meteorological Organisation (WMO), 1992].

When atmospheric bromine chemistry is compared to chlorine chemistry, it can be seen that much more bromine is present in the active forms $\mathrm{Br}$ and $\mathrm{BrO}$ than chlorine is present in their counterparts $\mathrm{Cl}$ and $\mathrm{ClO}$. Consequently, bromine has a greater potential to destroy stratospheric ozone than does chlorine [e.g. $W M O, 1990,1992]$.

Section 2 describes the photochemical model used in this study, which contains a detailed photochemistry scheme. Section 3 gives a budget study of atmospheric bromine species based on the current knowledge of gas phase bromine chemistry. Section 4 considers the effectiveness of the various ozone-destroying catalytic bromine cycles. Section 5 summarizes the main conclusions.

\section{Model Description}

The column model used in this study is a version of a new suite of models called AutoChEM. The model included a total of 53 species. No family or photochemical equilibrium assumptions are made. Of the 53 species, 51 species are integrated separately with a 15 minute time step, namely: $\mathrm{O}\left({ }^{1} \mathrm{D}\right), \mathrm{O}\left({ }^{3} \mathrm{P}\right), \mathrm{O}_{3}$, $\mathrm{N}, \mathrm{NO}, \mathrm{NO}_{2}, \mathrm{NO}_{3}, \mathrm{~N}_{2} \mathrm{O}_{5}, \mathrm{HONO}, \mathrm{HNO}_{3}, \mathrm{HNO}_{3(\mathrm{~S})}$, $\mathrm{HO}_{2} \mathrm{NO}_{2}, \mathrm{Cl}, \mathrm{Cl}_{2}, \mathrm{ClO}, \mathrm{ClOO}, \mathrm{OClO}, \mathrm{Cl}_{2} \mathrm{O}_{2}, \mathrm{ClNO}_{2}$, 
$\mathrm{ClONO}_{2}, \mathrm{HCl}, \mathrm{HCl}_{(\mathrm{s})}, \mathrm{HOCl}, \mathrm{H}, \mathrm{OH}, \mathrm{HO}_{2}, \mathrm{H}_{2} \mathrm{O}_{2}, \mathrm{CH}_{3}$, $\mathrm{CH}_{3} \mathrm{O}_{2}, \mathrm{CH}_{3} \mathrm{O}_{2} \mathrm{NO}_{2}, \mathrm{CH}_{3} \mathrm{OOH}, \mathrm{CH}_{3} \mathrm{O}, \mathrm{HCHO}, \mathrm{HCO}$, $\mathrm{Br}, \mathrm{Br}_{2}, \mathrm{BrO}, \mathrm{BrONO}_{2}, \mathrm{BrONO}, \mathrm{HBr}, \mathrm{HOBr}, \mathrm{BrCl}$, $\mathrm{H}_{2}, \mathrm{H}_{2} \mathrm{O}, \mathrm{H}_{2} \mathrm{O}_{(\mathrm{s})}, \mathrm{CO}, \mathrm{CO}_{2}, \mathrm{CH}_{4}, \mathrm{~N}_{2} \mathrm{O}, \mathrm{CH}_{3} \mathrm{Br}$ and $\mathrm{CF}_{2} \mathrm{Cl}_{2} . \mathrm{O}_{2}$ and $\mathrm{N}_{2}$ are included but not time integrated. The version of AutoChEM used in this study contains a total of 236 reactions, 129 bimolecular reactions, 27 trimolecular reactions, 42 photochemical reactions and 38 heterogeneous reactions. The rate constants for the reactions were taken from Atkinson et al. [1992] and DeMore et al. [1994].

The time integration scheme used is an adaptive timestep Burlisch-Stoer scheme [Stoer and Burlisch, 1980 specifically designed for integration of stiff systems after Press et al. [1992]. The time integration package is as accurate as the often used Gear [1971] package but faster. Photolysis rates are calculated by using full spherical geometry and multiple scattering as described by Lary and Pyle [1992a,b] after Meier et al. [1982], Nicolet et al. [1982] and Anderson [1983]. The average photolysis rate over a model time step is calculated using 10 point gaussian quadrature as described by Press et al. [1992].

AutoChem has also been used to perform for the first time four-dimensional variational analysis of chemical species [Fisher and Lary, 1995] and to examine the effect of the reaction $\mathrm{OH}+\mathrm{ClO} \rightarrow \mathrm{HCl}+\mathrm{O}_{2}$ on polar ozone photochemistry [Lary et al., 1995].

\section{Gas Phase Bromine Chemistry}

This section examines the budgets of reactive bromine species as predicted by our current understanding of the gas phase kinetics of bromine. Figure 1 is a reaction scheme of atmospheric bromine photochemistry. Het- erogeneous nitrogen and chlorine reactions are considered in these calculations but not heterogeneous bromine reactions. Heterogeneous bromine reactions are the subject of the companion paper Lary et al. [this issue]. The reactive bromine species included in AUTOCHEM are $\mathrm{Br}, \mathrm{Br}_{2}, \mathrm{BrO}, \mathrm{BrONO}, \mathrm{BrONO}_{2}, \mathrm{HBr}, \mathrm{HOBr}$ and $\mathrm{BrCl}$.

Figure 2 shows the calculated midlatitude photochemical lifetimes of these species for local noon at equinox, and Figure 3 shows the calculated midlatitude partitioning of reactive bromine species for local noon at equinox.

It can be seen from Figure 2 that in marked contrast to their chlorine counterparts all of the bromine species are short-lived. Figure 3 shows that typically the most abundant inorganic bromine species in the lower stratosphere are $\mathrm{BrO}, \mathrm{BrONO}_{2}$ and $\mathrm{HOBr}$. Each of the reactive bromine species will now be considered in turn.

\section{$\mathrm{BrONO}_{2}$}

$\mathrm{BrONO}_{2}$ has a photochemical lifetime of a few minutes throughout the sunlit middle atmosphere (the solid squares in the right-hand panel of Figure 2). The relatively short lifetime of $\mathrm{BrONO}_{2}$ is due to the photolysis of $\mathrm{BrONO}_{2}$, which occurs in the visible region of the spectrum. Consequently, $\mathrm{BrONO}_{2}$ is very close to photochemical steady state in the sunlit atmosphere. The recent study of Burkholder et al. [1995] measured the absorption cross section of $\mathrm{BrONO}_{2}$ in the important tail region between about $390 \mathrm{~nm}$ and $500 \mathrm{~nm}$ extending the previous measurements of Spencer and Rowland [1978]. As pointed out by Burkholder et al. [1995], if the products are $\mathrm{BrO}$ and $\mathrm{NO}_{2}$ then $\mathrm{BrONO}_{2}$ will not be involved in catalytic ozone destruction. Photolysis would merely reverse the formation of $\mathrm{BrONO}_{2}$. How-

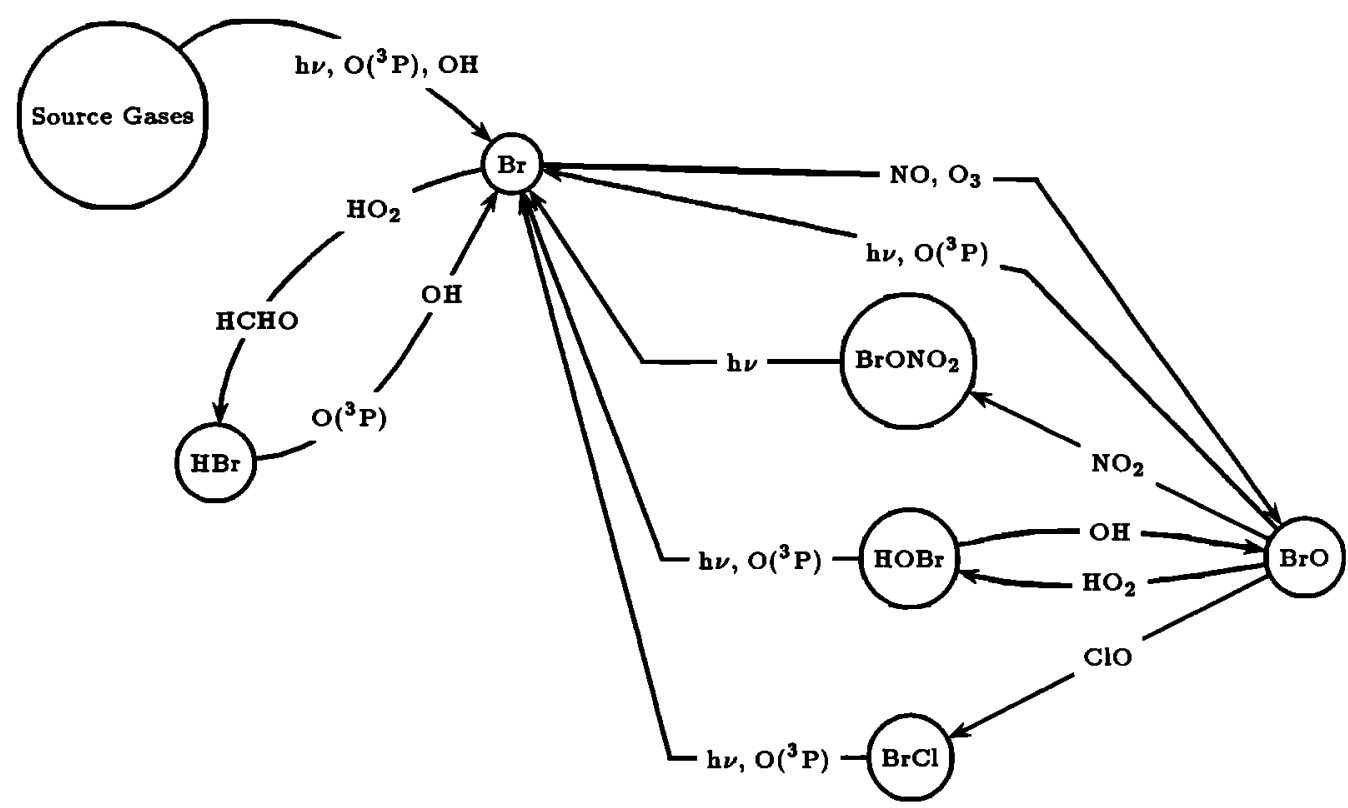

Figure 1. Schematic of atmospheric bromine photochemistry. 


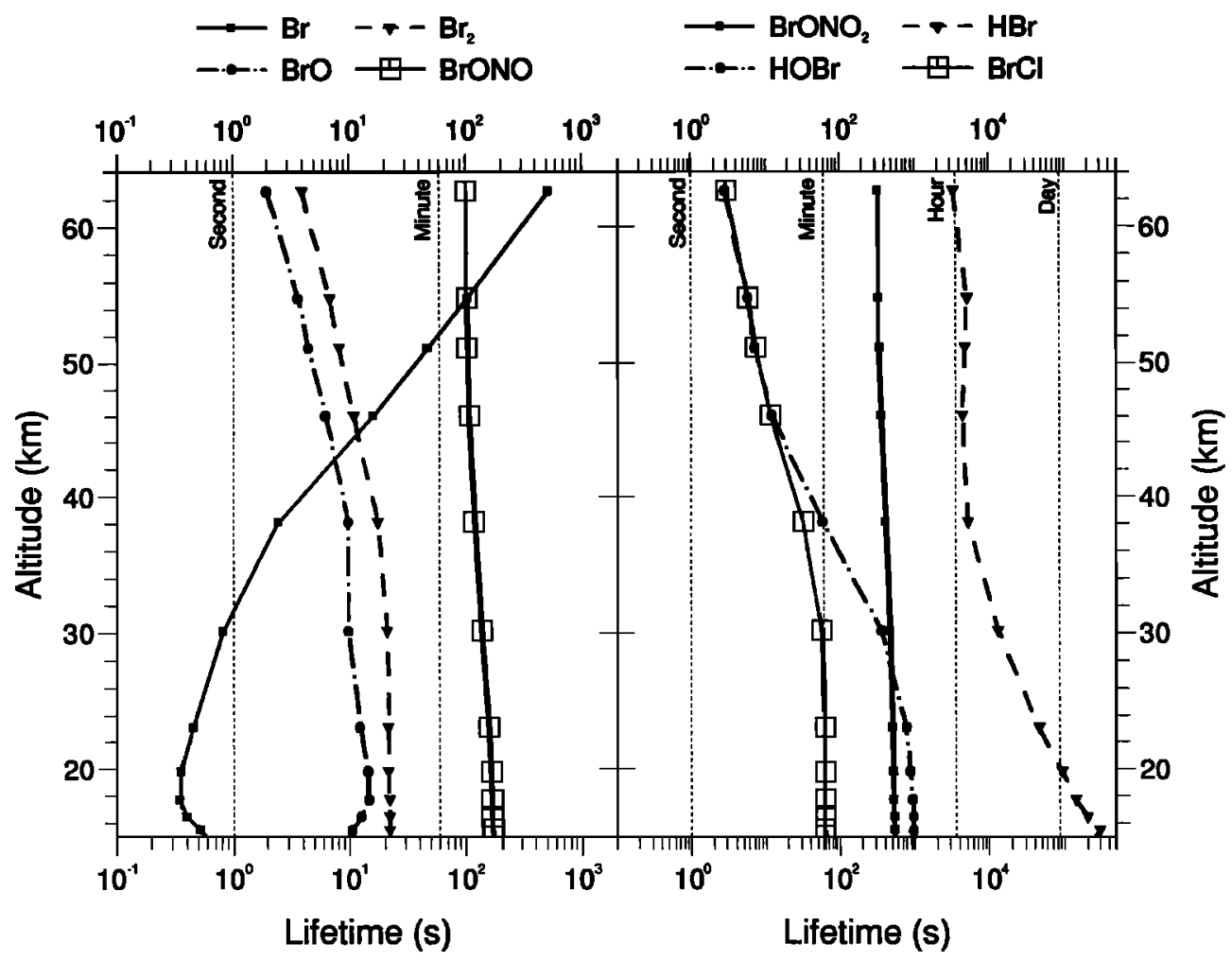

Local Noon, Mid-latitude at Equinox. No heterogeneous Bromine reactions

The reaction $\mathrm{BrO}+\mathrm{HO}_{2} \rightarrow \mathrm{HBr}+\mathrm{O}_{3}$ is not included

Figure 2. The calculated midlatitude photochemical lifetimes of reactive bromine species for local noon at equinox. Heterogeneous bromine reactions were not included in these calculations. These simulations do not include the reaction $\mathrm{HO}_{2}+\mathrm{BrO} \longrightarrow \mathrm{HBr}+\mathrm{O}_{3}$.

ever, if the products are $\mathrm{Br}$ and $\mathrm{NO}_{3}$, then an important catalytic destruction of ozone can occur. This catalytic destruction of ozone will be considered in the next section.

$\mathrm{BrONO}_{2}$ is produced by the three-body reaction of $\mathrm{BrO}$ with $\mathrm{NO}_{2}$. Because $\mathrm{BrONO}{ }_{2}$ has a relatively short lifetime, the $\mathrm{BrONO}_{2}$ concentration responds very rapidly to any change in $\mathrm{NO}_{2}$, as occurs, for example, due to denoxification on surfaces. The rate recommended for the formation of $\mathrm{BrONO}_{2}$ by DeMore et al. [1992] is based on kinetic measurements made by Thorn et al. [1993] and Danis et al. [1990]. These measurements were made at over $260 \mathrm{~K}$ and so quite large temperature extrapolations are involved when considering lower stratospheric temperatures. It would therefore be valuable to have further measurement studies of this reaction at the colder temperatures experienced in the lower stratosphere.

The companion paper Lary et al. [this issue] shows that the catalytic hydrolysis of $\mathrm{BrONO}_{2}$ on sulfate aerosols is an important sink of $\mathrm{BrONO}_{2}$ in the lower stratosphere.

\section{HOBr}

In the sunlit atmosphere, $\mathrm{HOBr}$ is almost in immediate photochemical steady state with a lifetime of sev- eral minutes in the lower stratosphere decreasing to a few seconds in the upper stratosphere (the solid circles in the right-hand panel of Figure 2). In the sunlit lower stratosphere $\mathrm{HOBr}$ represents between approximately $20 \%$ and $30 \%$ of the total $\mathrm{BrO}_{y}=$ total inorganic bromine (the solid circles in the right-hand panel of Figure 3). The main source of $\mathrm{HOBr}$ is the reaction

$$
\begin{aligned}
& \mathrm{BrO}+\mathrm{HO}_{2} \longrightarrow \mathrm{HOBr}+\mathrm{O}_{2} \\
& k=6 \times 10^{-12} \mathrm{e}^{+\frac{500}{\mathrm{~T}}} \quad \Delta \mathrm{H}_{\mathrm{f}} 298 \mathrm{~K}=-217.7 \mathrm{~kJ} / \mathrm{Mole} \\
& \mathrm{BrO}+\mathrm{HO}_{2} \longrightarrow \mathrm{HBr}+\mathrm{O}_{3} \\
& \text { Possible minor channel } \Delta \mathrm{H}_{\mathrm{f}} 298 \mathrm{~K}=-31.8 \mathrm{~kJ} / \mathrm{Mole}
\end{aligned}
$$

The units of this, and all subsequent rate constants, are molecules $\mathrm{cm}^{-3} \mathrm{~s}^{-1}$. Recent laboratory measurements of reaction (1) were made by Poulet et al. [1992] and of reaction (1b) by Mellouki et al. [1994]. The effect of $\mathrm{HBr}$ production by reaction (1b) is considered below in the subsection on $\mathrm{HBr}$.

As can be seen in the companion paper Lary et al. [this issue], in the troposphere and lower stratosphere, the heterogeneous production of $\mathrm{HOBr}$ on sulfate aerosols can play an important role:

$\mathrm{H}_{2} \mathrm{O}+\mathrm{BrONO}_{2} \longrightarrow \mathrm{HOBr}+\mathrm{HNO}_{3}$ 


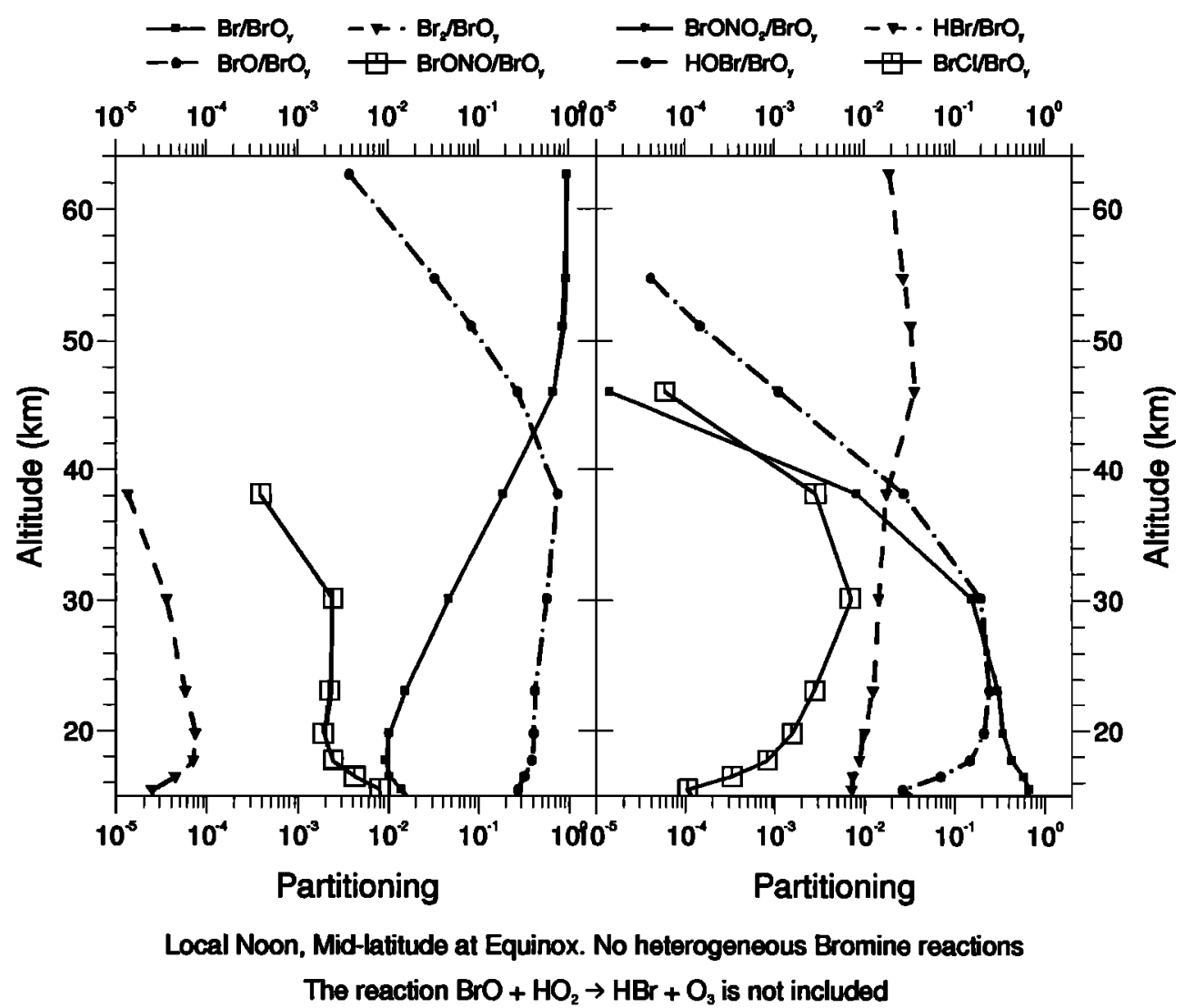

Figure 3. The calculated midlatitude partitioning of reactive bromine species for local noon at equinox.

(see also Fan and Jacob [1992] and Hanson and Ravishankara [1995]). HOBr destruction is due to photolysis and the reaction with $O\left({ }^{3} \mathrm{P}\right)$. The rate constant for the reaction of $\mathrm{HOBr}$ with $\mathrm{O}\left({ }^{3} \mathrm{P}\right)$ has recently been determined by Nesbitt et al. [1995].

$$
\begin{gathered}
\mathrm{HOBr}+\mathrm{h} \nu \rightarrow \mathrm{Br}+\mathrm{OH} \\
\text { Orlando and Burkholder [1995] } \\
\mathrm{HOBr}+\mathrm{O}\left({ }^{3} \mathrm{P}\right) \rightarrow \mathrm{OH}+\mathrm{BrO} \\
k=1.4 \times 10^{-10} \mathrm{e}^{-\frac{430}{\mathrm{~T}}}
\end{gathered}
$$

Below approximately $25 \mathrm{~km}$ photolysis is the most important loss of $\mathrm{HOBr}$, whereas above this altitude the reaction with $\mathrm{O}\left({ }^{3} \mathrm{P}\right)$ is the main loss of $\mathrm{HOBr}[$ Nesbitt et al., 1995]. This confirms the findings of Nesbitt et al. [1995]. The lifetime of $\mathrm{HOBr}$ varies from about 15 minutes in the sunlit lower stratosphere to a few seconds in the upper stratosphere. This is based on calculations using the $\mathrm{HOBr}$ absorption cross section which have recently been measured for the first time by Orlando and Burkholder [1995].

\section{BrO}

The most abundant bromine species in the sunlit lower stratosphere is normally $\mathrm{BrO}$, which has a lifetime of a few seconds (the solid circles in the left hand panel of Figure 2). Typically, at $20 \mathrm{~km}$, approximately $40 \%$ of $\mathrm{BrO}_{y}$ is in the form of $\mathrm{BrO}$ rising to a peak of about $75 \%$ at around $40 \mathrm{~km}$ (the solid circles in the left-hand panel of Figure 3). The main source of $\mathrm{BrO}$ is the reaction

$$
\mathrm{Br}+\underset{k=1.7 \times 10^{-11} \mathrm{e}^{-\frac{800}{\mathrm{~T}}}}{\mathrm{OrO}}+\mathrm{O}_{2}
$$

In the sunlit lower stratosphere the main destruction of $\mathrm{BrO}$ is by photolysis (the peak $\mathrm{BrO}$ absorption is at around $325 \mathrm{~nm}$ ) and reaction with NO

$$
\begin{aligned}
& \mathrm{BrO}+\mathrm{h} \nu \rightarrow \mathrm{Br}+\mathrm{O}\left({ }^{3} \mathrm{P}\right) \\
& \text { DeMore et al. }[1992] \\
& \mathrm{BrO}+\mathrm{NO} \longrightarrow \underset{\mathrm{Br}}{\longrightarrow}+\mathrm{NO}_{2} \\
& \quad k=8.7 \times 10^{-12} \mathrm{e}^{-\frac{360}{T}}
\end{aligned}
$$

In the upper stratosphere the main loss of $\mathrm{BrO}$ is due to the reaction

$$
\begin{aligned}
& \mathrm{BrO}+\mathrm{O}\left({ }^{3} \mathrm{P}\right) \rightarrow \mathrm{O}_{2}+\mathrm{Br} \\
& k=3 \times 10^{-11}
\end{aligned}
$$

In the lower stratosphere the reaction of $\mathrm{BrO}$ with $\mathrm{ClO}$ contributes a few percent to the loss rate of $\mathrm{BrO}$. Close to the ground the reaction of $\mathrm{BrO}$ with $\mathrm{HO}_{2}$, men- 
tioned above, contributes about $10 \%$ to the total loss of $\mathrm{BrO}$, as does the formation of $\mathrm{BrONO}_{2}$. As will be discussed later, the reaction of $\mathrm{BrO}$ with $\mathrm{ClO}$ is also important for catalytic ozone destruction.

\section{$\mathbf{H B r}$}

Although $\mathrm{HBr}$ is the longest lived $\mathrm{BrO}_{y}$ reservoir, it still has a lifetime of only about a day in the sunlit midlatitude lower stratosphere, decreasing to an hour in the upper stratosphere (the triangles in the righthand panel of Figure 2). The lifetime does increase at high latitudes during winter where there is less sunlight. According to our current understanding, generally only a small percent of $\mathrm{BrO}_{y}$ in the lower stratosphere is in the form of $\mathrm{HBr}$ (the triangles in the right-hand panel of Figure 3). However, in the troposphere, $\mathrm{HBr}$ is generally a larger fraction of the total $\mathrm{BrO}_{y}$. Typically between about $10 \%$ and $40 \%$ of tropospheric $\mathrm{BrO}_{y}$ can be in the form of $\mathrm{HBr}$ if heterogeneous bromine reactions are not considered and if it is assumed that there is negligible production of $\mathrm{HBr}$ by reaction (1B) above. However, as will be seen in the companion paper Lary et al. [this issue], if heterogeneous bromine reactions do occur $\mathrm{HBr}$ may be only a very small fraction of the total $\mathrm{BrO}_{y}$ present both in the troposphere and lower stratosphere.

$\mathrm{HBr}$ is produced mainly by the reactions

$$
\begin{gathered}
\mathrm{Br}+\mathrm{HO}_{2} \rightarrow \underset{k=1.4 \times 10^{-11} \mathrm{e}^{-\frac{590}{\mathrm{~T}}}}{\mathrm{HBr}}+\mathrm{O}_{2} \\
\mathrm{Br}+\mathrm{HCHO} \longrightarrow \mathrm{HBr}+\mathrm{HCO} \\
k=1.7 \times 10^{-11} \mathrm{e}^{-\frac{800}{\mathrm{~T}}}
\end{gathered}
$$

At around $20 \mathrm{~km}$ at equinox in the sunlit lower stratosphere reactions (9) and (10) make a significant contribution to $\mathrm{HBr}$ production. However, as shall be seen later, the reaction of $\mathrm{Br}$ with $\mathrm{HCHO}$ can sometimes become the most important source of $\mathrm{HBr}$ in the lower stratosphere. In the upper stratosphere the importance of reaction (10) decreases and reaction (9) is the main source of $\mathrm{HBr}$, whereas the main source of $\mathrm{HBr}$ in the model troposphere is reaction (10). In the very low stratosphere and troposphere the higher aldehydes probably also play a role in producing $\mathrm{HBr}$.

Below about $50 \mathrm{~km}, \mathrm{HBr}$ is destroyed mainly by reaction with $\mathrm{OH}$. Above $50 \mathrm{~km}$ the reaction of $\mathrm{HBr}$ with $\mathrm{O}\left({ }^{3} \mathrm{P}\right)$ also becomes an important loss of $\mathrm{HBr}$.

$$
\begin{gathered}
\mathrm{HBr}+\mathrm{OH} \longrightarrow \mathrm{H}_{2} \mathrm{O}+\mathrm{Br} \\
\mathrm{HBr}+1.1 \times 10^{-11} \\
+\mathrm{O}\left({ }^{3} \mathrm{P}\right) \longrightarrow \mathrm{OH}+\mathrm{Br} \\
k=6.6 \times 10^{-12} \mathrm{e}^{-\frac{1540}{\mathrm{~T}}}
\end{gathered}
$$

The partitioning of reactive bromine is very sensitive to the branching ratio of reaction (1) in the lower stratosphere. Even a very small yield of $\mathrm{HBr}$ will in- crease the $\mathrm{HBr}$ concentration at the expense of $\mathrm{HOBr}$. To illustrate this, Figure 4 shows that an $\mathrm{HBr}$ yield of only $0.1 \%$ would double the $\mathrm{HBr}$ concentration at $20 \mathrm{~km}$ and a yield of $1 \%$ would give a tenfold increase in $\mathrm{HBr}$ at $20 \mathrm{~km}$. If it were assumed that reaction (1b) had a yield of $0.1 \%$, then between $60 \%$ and $70 \%$ of the $\mathrm{HBr}$ produced at around $20 \mathrm{~km}$ would be due to reaction (1b); if the yield is $1 \%$ then between $80 \%$ and $90 \%$ of the $\mathrm{HBr}$ produced at around $20 \mathrm{~km}$ is due to reaction (1b). The partitioning of reactive bromine is affected by the assumed yield of $\mathrm{HBr}$ from reaction (1) up to about $50 \mathrm{~km}$, above this altitude the effect on the $\mathrm{HBr}$ concentration is relatively small.

Garcia and Solomon [1994] have recently examined the effect of assuming different branching ratios for reaction (1). They found that the $\mathrm{BrO}$ abundance was critically dependent on the yield of $\mathrm{HBr}$. Their comparison between model calculations and observations suggests that the yield must be substantially less than $5 \%$.

Laboratory measurements of reaction (1) were made by Poulet et al. [1992]. They pointed out that $\mathrm{HBr}$ is a possible product of this reaction but stated that the only product they observed at $298 \mathrm{~K}$ was $\mathrm{HOBr}$ suggesting a negligible yield for $\mathrm{HBr}$. They did not preclude the formation of $\mathrm{HOBr}$ at the lower temperatures of the stratosphere. Reaction ( $1 \mathrm{~b}$ ) is a four-centered reaction and because of the required reaction geometry these reactions are generally very slow. An upper limit on the yield of $\mathrm{HBr}$ from reaction (1b) has recently been determined by Mellouki et al. [1994] by measuring an upper limit for the reverse reaction. The limits were measured at $301 \mathrm{~K}$ and $441 \mathrm{~K}$ and were extrapolated to low temperatures. They found that the yield of $\mathrm{HBr}$ from reaction (1b) is negligible throughout the stratosphere. It is likely that less than $0.01 \%$ of reaction (1) yields $\mathrm{HBr}$ as a product.

Since the yield of $\mathrm{HBr}$ from reaction (1) would affect the fraction of $\mathrm{BrO}_{y}$ in the form of $\mathrm{BrO}$ it would also affect the $\mathrm{OClO}$ concentration, since $\mathrm{OClO}$ is produced mainly by reaction (15). Increasing the yield of $\mathrm{HBr}$ from reaction (1) from $0 \%$ to $1 \%$ would reduce the large nighttime OClO column by just over $16 \%$ at midlatitudes.

Our current understanding of bromine photochemistry suggests that the main sources of $\mathrm{HBr}$ are reactions (9) and (10). For all of these reactions both the reactants are present in the atmosphere in relatively small concentrations. This is in contrast to $\mathrm{HCl}$, which is formed mainly by the reaction of $\mathrm{Cl}$ with the relatively abundant $\mathrm{CH}_{4}$. The extensive literature review of Baulch et al. [1981] quotes a rate constant for the analogous bromine reaction which is very slow at stratospheric temperatures

$$
\mathrm{Br}+\underset{k=7.8 \times 10^{-11} \mathrm{e}^{-\frac{9180}{\mathrm{~T}}}}{\mathrm{CH}_{4}} \longrightarrow \mathrm{CH}_{3}
$$

A reaction which may play a roie in the troposphere 


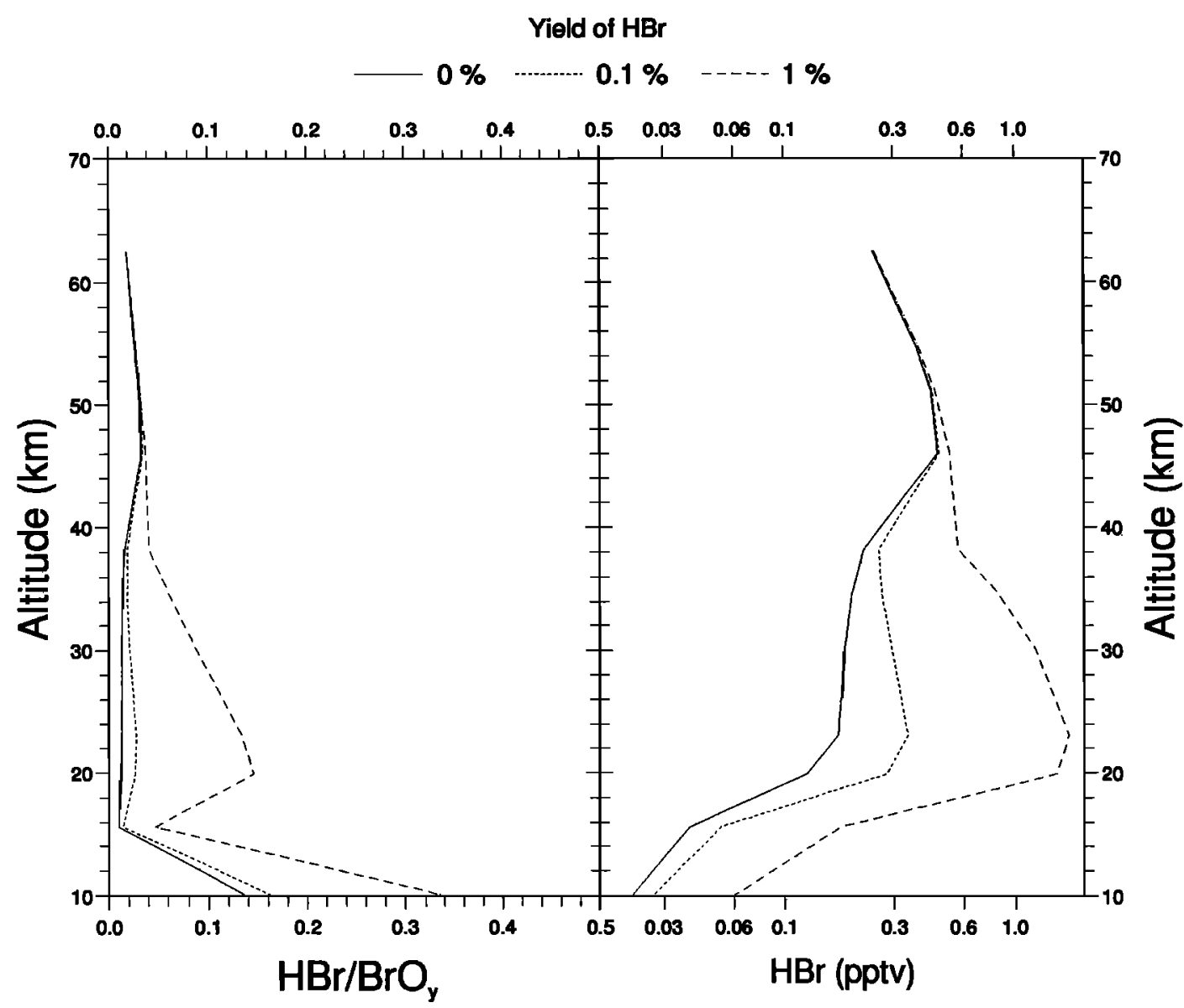

Figure 4. The calculated midlatitude concentration and fraction of $\mathrm{BrO}_{y}$ present as $\mathrm{HBr}$ for local noon at equinox if $0 \%, 0.1 \%$ and $1 \%$ of the reaction of $\mathrm{HO}_{2}$ with $\mathrm{BrO}$ yields $\mathrm{HBr}$. Heterogeneous bromine reactions were not included in these calculations.

and lower stratosphere is

$$
\mathrm{Br}+\mathrm{H}_{2} \mathrm{O}_{2} \underset{k<5 \times 10^{-16}}{\longrightarrow} \mathrm{HBr}+\mathrm{HO}_{2}
$$

There have been five different studies of reaction (14) by Leu [1980], Posey et al. [1981], Heneghan and Benson [1983], Toohey et al. [1987] and Mellouki et al. [1994]. Apart from Heneghan and Benson [1983] all show that $\mathrm{Br}$ has a very low reactivity towards $\mathrm{H}_{2} \mathrm{O}_{2}$. Mellouki et al. [1994] suggest that this discrepancy may have been due to some reactive impurity from the microwave discharge source used by Heneghan and Benson [1983].

Mellouki et al. [1994] also considered the loss of $\mathrm{HBr}$ due to its reaction with $\mathrm{HO}_{2}$. They concluded that there was no measurable evidence for this reaction. If there is an additional source of $\mathrm{HBr}$ which could proceed at a rate comparable to reaction (1), it would considerably affect our understanding of the partitioning of reactive bromine.

\section{$\mathbf{B r}$}

$\mathrm{Br}$ constitutes about $1 \%$ of $\mathrm{BrO}_{y}$ in the sunlit lower stratosphere, where it is in photochemical steady state with a lifetime of about half a second (the solid squares in the left-hand panel of Figure 2). At $30 \mathrm{~km}$ approximately $10 \%$ of $\mathrm{BrO}_{y}$ is in the form of $\mathrm{Br}$ rising to over $90 \%$ above $50 \mathrm{~km}$ (the solid squares in the left-hand panel of Figure 3). This is in contrast to $\mathrm{Cl}$, which in the lower stratosphere typically constitutes only around $0.001 \%$ of the total $\mathrm{ClO}_{y}$ (=Total inorganic chlorine), increasing to about $4 \%$ in the upper stratosphere. As one descends through the group of halogens from fluorine through to iodine, the partitioning shifts towards the more reactive species. Throughout most of the middle atmosphere the most important loss of $\mathrm{Br}$ is reaction with $\mathrm{O}_{3}$ and the two most important sources of $\mathrm{Br}$ are the photolysis of $\mathrm{BrO}$ (reaction (6)) and the reaction of $\mathrm{BrO}$ with $\mathrm{NO}$ (reaction (7)). In the upper stratosphere the reaction of $\mathrm{BrO}$ with $\mathrm{O}\left({ }^{3} \mathrm{P}\right)$ is the most important source of $\mathrm{Br}$ (reaction (8)). Two channels of the reaction of $\mathrm{BrO}$ with $\mathrm{ClO}$ contribute a few percent to the production of $\mathrm{Br}$ in the sunlit lower stratosphere (reactions (15) and (15) below), as does the photolysis of $\mathrm{HOBr}$ and $\mathrm{BrONO}_{2}$.

\section{BrCl}

The lifetime of $\mathrm{BrCl}$ in the sunlit lower stratosphere is approximately a minute (the open squares in the right-hand panel of Figure 2). During the day $\mathrm{BrCl}$ 
generally constitutes much less than $1 \%$ of $\mathrm{BrO}_{y}$ in the lower stratosphere (Figure 3) when no heterogeneous reactions have occurred on polar stratospheric clouds (PSCs) for a long time. When PSCs, or cold sulfate aerosols, are encountered, the $\mathrm{BrCl}$ concentration rapidly increases and $\mathrm{BrCl}$ can become a sizable fraction of the total $\mathrm{BrO}_{y} . \mathrm{BrCl}$ is typically the major nighttime reservoir of $\mathrm{BrO}_{y}$ when PSCs are present. The gas phase production of $\mathrm{BrCl}$ is almost entirely due to reaction (17):

$$
\begin{aligned}
\mathrm{BrO}+\mathrm{ClO} \longrightarrow \mathrm{Br}+\mathrm{OClO} \\
k=1.6 \times 10^{-12} \mathrm{e}^{-\frac{430}{\mathrm{~T}}} \\
\mathrm{BrO}+\mathrm{ClO} \rightarrow \mathrm{Br}+\mathrm{ClOO} \\
k=2.9 \times 10^{-12} \mathrm{e}^{-\frac{220}{T}} \\
\mathrm{BrO}+\mathrm{ClO} \longrightarrow \mathrm{BrCl}+\mathrm{O}_{2} \\
k=5.8 \times 10^{-13} \mathrm{e}^{-\frac{170}{\mathrm{~T}}}
\end{aligned}
$$

The reaction of $\mathrm{BrO}$ with $\mathrm{ClO}$ is an important reaction as it is the first step in the catalytic loss of ozone due to the cycle described in the next section. The loss of $\mathrm{BrCl}$ below about $30 \mathrm{~km}$ is almost entirely due to photolysis, the peak $\mathrm{BrCl}$ absorption is at around $375 \mathrm{~nm}$ (Seery and Britton [1964], R. A. Cox, private communication [1993]). Above about $30 \mathrm{~km}$ the main loss of $\mathrm{BrCl}$ is due to the reaction with $\mathrm{O}\left({ }^{3} \mathrm{P}\right)$. This reaction is not normally included in numerical models but its rate was determined by Clyne et al. [1976].

$$
\begin{gathered}
\mathrm{BrCl}+\mathrm{h} \nu \rightarrow \mathrm{Br}+\mathrm{Cl} \\
\text { Seery and Britton }[1964] \\
\mathrm{BrCl}+\mathrm{O}\left({ }^{3} \mathrm{P}\right) \rightarrow \mathrm{BrO}+\mathrm{Cl} \\
k=2.2 \times 10^{-11}
\end{gathered}
$$

\section{Catalytic Cycles}

There are several important chain reactions involving atmospheric bromine species. These chains can propagate after an initiation step transforming reactants into products by repeated cycles of the chain. The length of these cycles is limited by termination steps which destroy the chain centre, or radical, involved in the cycle. The chain length is a measure of how many times the cycle is executed before the chain centre is removed. The chain length, $\mathcal{N}$, is usually defined as the rate of propagation (the rate of the rate-limiting step), $\mathbf{k}_{\mathrm{rls}} \mathrm{di}$ vided by the rate of production or destruction of the chain center, $\mathrm{k}_{\text {dest }}$.

$$
\text { chain length, } \mathcal{N}=\mathbf{k}_{\text {rls }} / \mathbf{k}_{\text {dest }}
$$

In the atmosphere there are a very large number of interacting and competing cycles occurring. Therefore, a more useful definition has been used which defines the chain length in terms of the destruction of the long- lived source gases, such as $\mathrm{CH}_{3} \mathrm{Br}$, instead of in terms of the production or destruction of a specific chain centre, such as $\mathrm{Br}$ or $\mathrm{BrO}$. Because the chain length is a ratio of two rates it is dimensionless.

If a particular radical is involved in a catalytic cycle which has a very long chain length, but it is only present in small concentrations, the effectiveness of the cycle will be limited. It is therefore useful to define a new variable, which shall be called the chain effectiveness, as the chain length multiplied by the rate of the cycle's rate-limiting step. The chain effectiveness enables a fair comparison to be made of different catalytic cycles involving species which have very different concentrations.

$$
\text { chain effectiveness, } \mathcal{E}=\mathrm{k}_{\mathrm{rls}} \mathcal{N}
$$

This section considers the chain length and chain effectiveness of the various atmospheric bromine catalytic cycles as a function of altitude compared with other catalytic cycles which are of importance in the atmosphere. Because this paper focuses on the gas phase chemistry of atmospheric bromine, the situation chosen was noon for midlatitudes at the equinox.

As was seen earlier, all of the atmospheric bromine species are relatively short lived. Therefore, the termination steps of the gas phase bromine cycles which involve the formation of $\mathrm{HBr}$ or $\mathrm{BrONO}_{2}$ are not very effective since the $\mathrm{Br}$ or $\mathrm{BrO}$ can easily be liberated from these species. In fact, $\mathrm{BrONO}_{2}$ is itself involved in the catalytic heterogeneous destruction of ozone [Lary et al., this issue], so formation of $\mathrm{BrONO}_{2}$ is not even the termination of a chain. This is in marked contrast to the $\mathrm{Cl} / \mathrm{ClO}$ and $\mathrm{NO} / \mathrm{NO}_{2}$ catalytic cycles, where the formation of the reservoirs $\mathrm{HCl}$ and $\mathrm{HNO}_{3}$ is an effective termination of the chain reactions. Consequently, the bromine chain reactions tend to have longer chain lengths than their chlorine counterparts. Catalytic ozone loss can be due to several cycles involving bromine (Figure 5), which will now be considered in turn.

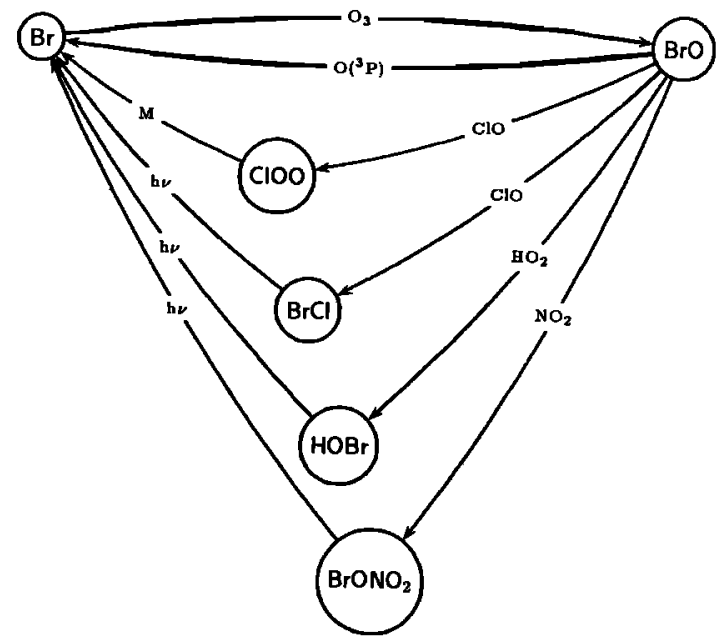

Figure 5. The bromine gas phase catalytic ozone destruction cycles. 

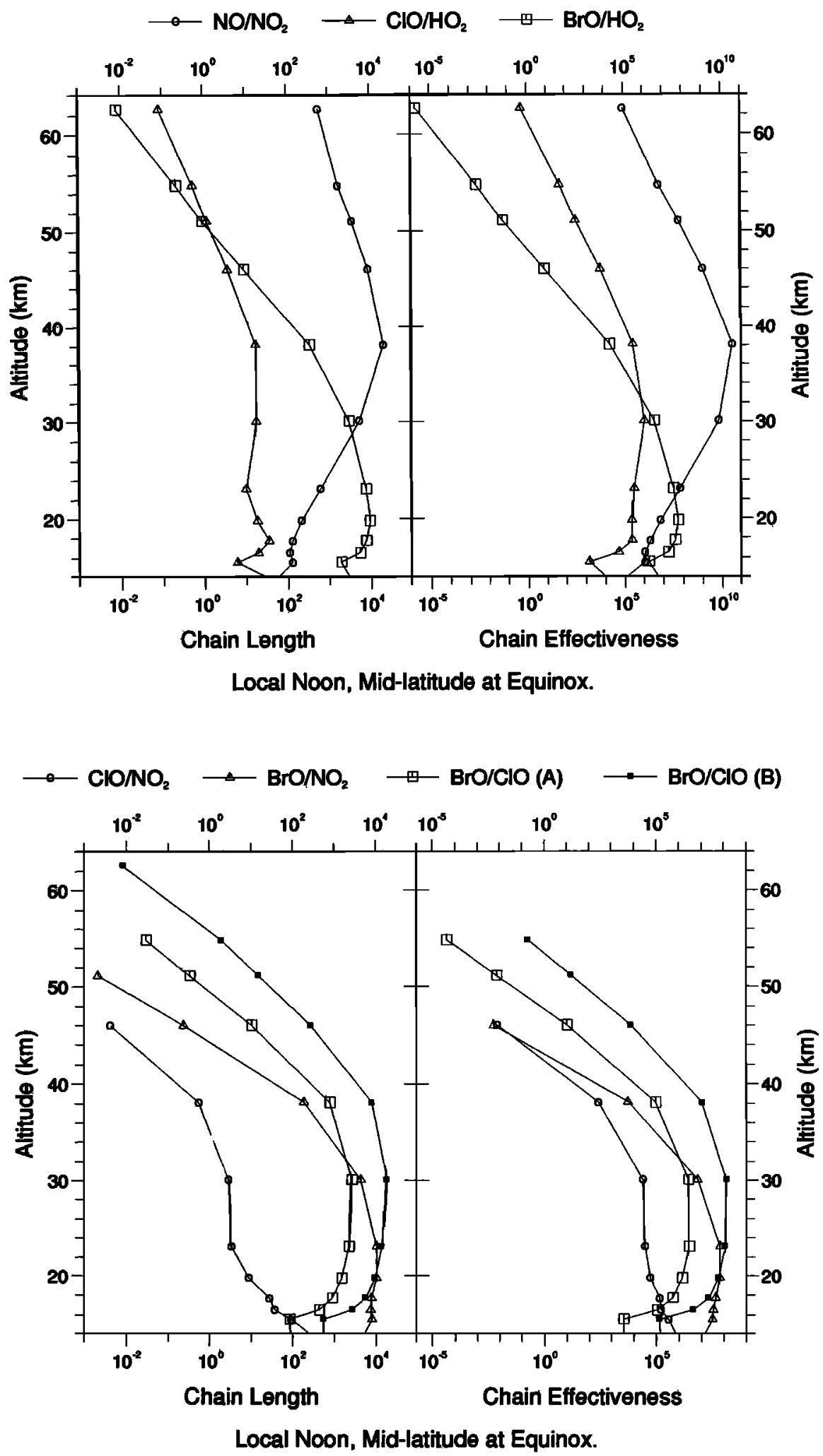

Figure 6. The calculated midlatitude chain length and chain effectiveness of various catalytic cycles for local noon at equinox. The chain effectiveness is the chain length multiplied by the rate of the cycle's rate-limiting step and has units of molecules $\mathrm{cm}^{-3} \mathrm{~s}^{-1}$. 


\section{$\mathrm{BrO} / \mathrm{ClO}$}

In polar regions the coupling of $\mathrm{BrO}$ and $\mathrm{ClO}$ chemistry via the $\mathrm{BrO} / \mathrm{ClO}$ catalytic cycle is particularly important. The coupling is also important at midlatitudes. The $\mathrm{BrO} / \mathrm{ClO}$ cycle can operate via two routes. One route, here referred to as route $A$, results in the formation of $\mathrm{BrCl}$ :

\begin{tabular}{|c|c|c|c|c|c|c|}
\hline $\mathrm{BrO}$ & + & $\mathrm{ClO}$ & $\longrightarrow$ & $\mathrm{BrCl}$ & + & $\mathrm{O}_{2}$ \\
\hline $\mathrm{BrCl}$ & + & $\mathrm{h} \nu$ & $\longrightarrow$ & $\mathrm{Br}$ & + & $\mathrm{Cl}$ \\
\hline $\mathrm{Br}$ & + & $\mathrm{O}_{3}$ & $\longrightarrow$ & $\mathrm{BrO}$ & + & $\mathrm{O}_{2}$ \\
\hline $\mathrm{Cl}$ & + & $\mathrm{O}_{3}$ & $\rightarrow$ & $\mathrm{ClO}$ & + & $\mathrm{O}_{2}$ \\
\hline
\end{tabular}

Depending on the physical conditions, in the low stratosphere below about $15 \mathrm{~km}$ the rate-limiting step is the formation of $\mathrm{BrCl}$. However, higher up in the stratosphere it is the photolysis of $\mathrm{BrCl}$.

In the sunlit stratosphere between 15 and $35 \mathrm{~km}$ this cycle has a chain length of approximately $10^{3}$ with the chain length decreasing above $35 \mathrm{~km}$ (Figure 6). The chain effectiveness of this cycle is approximately $10^{6}$ molecules $\mathrm{cm}^{-3} \mathrm{~s}^{-1}$ between about 17 and $30 \mathrm{~km}$ (Figure 6). This can be compared to the $\mathrm{NO} / \mathrm{NO}_{2}$ catalytic cycle [Crutzen, 1970; Johnston, 1971], which is the most important ozone loss cycle at $38 \mathrm{~km}$ where it has a chain length of $10^{4}$ and a chain effectiveness of approximately $10^{10}$ molecules $\mathrm{cm}^{-3} \mathrm{~s}^{-1}$, decreasing to $10^{6}$ molecules $\mathrm{cm}^{-3} \mathrm{~s}^{-1}$ at $17 \mathrm{~km}$ and $10^{2}$ molecules $\mathrm{cm}^{-3} \mathrm{~s}^{-1}$ at $10 \mathrm{~km}$ (Figure 6).

The alternative cycle, here referred to as route $B$, is much more effective than route $A$ and involves the formation of ClOO:

\begin{tabular}{lllll}
$\mathrm{BrO}$ & $+\mathrm{ClO}$ & $\longrightarrow$ & $\mathrm{Br}$ & $+\mathrm{ClOO}$ \\
$\mathrm{ClOO}$ & & & $\stackrel{\mathrm{M}}{\longrightarrow}$ & $\mathrm{Cl}+\mathrm{O}_{2}$ \\
$\mathrm{Br}$ & $+\mathrm{O}_{3}$ & $\longrightarrow$ & $\mathrm{BrO}+\mathrm{O}_{2}$ \\
$\mathrm{Cl}+\mathrm{O}_{3}$ & $\longrightarrow$ & $\mathrm{ClO}+\mathrm{O}_{2}$ \\
\hline $\mathrm{Net}$ & & $2 \mathrm{O}_{3}$ & $\longrightarrow$ & $3 \mathrm{O}_{2}$
\end{tabular}

The rate-limiting step is the formation of ClOO. Throughout the sunlit lower stratosphere this cycle has a chain length of approximately $10^{4}$ (Figure 6). The chain effectiveness of this cycle is approximately $10^{8}$ molecules $\mathrm{cm}^{-3} \mathrm{~s}^{-1}$ between about 20 and $30 \mathrm{~km}$ (Figure 6). Route $\mathrm{B}$ of the $\mathrm{ClO} / \mathrm{BrO}$ catalytic cycle is approximately an order of magnitude more effective at destroying ozone between 16 and $20 \mathrm{~km}$ than the $\mathrm{NO} / \mathrm{NO}_{2}$ catalytic cycle.

The efficiency of the $\mathrm{BrO} / \mathrm{ClO}$ cycle is reduced by the alternate channel of the $\mathrm{BrO}+\mathrm{ClO}$ reaction which yields $\mathrm{OClO}$ (reaction (15)). OClO is photolyzed to give an oxygen atom, this channel constitutes a null cycle.

\section{$\mathrm{BrO} / \mathrm{HO}_{2}$}

The $\mathrm{BrO} / \mathrm{HO}_{2}$ catalytic cycle involves the formation of $\mathrm{HOBr}$.

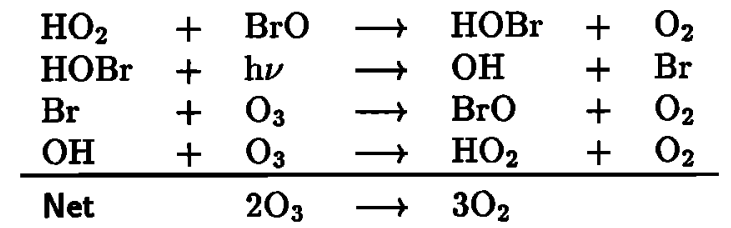

Below about $15 \mathrm{~km}$ the rate-limiting step is the photolysis of $\mathrm{HOBr}$; above this the formation of $\mathrm{HOBr}$ is the rate limiting step. In the sunlit lower stratosphere this cycle has a long chain length of approximately $10^{3}$ (Figure 6). The chain effectiveness of the $\mathrm{BrO} / \mathrm{HO}_{2}$ catalytic cycle is greater than $10^{6}$ molecules cm $\mathrm{cm}^{-3} \mathrm{~s}^{-1}$ between 13 and $30 \mathrm{~km}$. The chain length and effectiveness decrease above $35 \mathrm{~km}$. The $\mathrm{BrO} / \mathrm{HO}_{2}$ catalytic cycle is approximately 2 orders of magnitude more effective at destroying ozone at $12 \mathrm{~km}$ than the $\mathrm{NO} / \mathrm{NO}_{2}$ catalytic cycle, and twice as effective at $20 \mathrm{~km}$.

The analogous $\mathrm{ClO} / \mathrm{HO}_{2}$ catalytic cycle has a much shorter chain length of less than 50 above $15 \mathrm{~km}$, where the rate-limiting step is the photolysis of $\mathrm{HOCl}$ (Figure 6). The $\mathrm{ClO} / \mathrm{HO}_{2}$ chain length is approximately $10^{2}$ close to the tropopause and in the troposphere, where the rate-limiting step is the reaction of $\mathrm{OH}$ with $\mathrm{O}_{3}$. Between 15 and $20 \mathrm{~km}$ the $\mathrm{BrO} / \mathrm{HO}_{2}$ cycle is between 1 and 2 orders of magnitude more effective than the $\mathrm{ClO} / \mathrm{HO}_{2}$ cycle at destroying ozone, even though $\mathrm{BrO}$ is much less abundant than $\mathrm{ClO}$. This finding emphasizes the importance of atmospheric bromine for catalytic ozone destruction.

\section{$\mathrm{Br} / \mathrm{BrO}$}

The $\mathrm{Br} / \mathrm{BrO}$ catalytic cycle increases in length from $10^{2}$ in the lower stratosphere to $10^{4}$ in the upper stratosphere (Figure 6).

\begin{tabular}{llll}
$\mathrm{Br}+\mathrm{O}_{3}$ & $\rightarrow$ & $\mathrm{BrO}+\mathrm{O}_{2}$ \\
$\mathrm{BrO}+\mathrm{O}\left({ }^{3} \mathrm{P}\right)$ & $\rightarrow$ & $\mathrm{Br}+\mathrm{O}_{2}$ \\
\hline $\mathrm{O}_{3}+\mathrm{O}\left({ }^{3} \mathrm{P}\right)$ & $\longrightarrow$ & $2 \mathrm{O}_{2}$
\end{tabular}

At all sunlit altitudes the reaction of $\mathrm{BrO}$ with $\mathrm{O}\left({ }^{3} \mathrm{P}\right)$ is the rate limiting step. The chain effectiveness increases from $10^{3}$ molecules $\mathrm{cm}^{-3} \mathrm{~s}^{-1}$ at $12 \mathrm{~km}$ to $10^{9}$ molecules $\mathrm{cm}^{-3} \mathrm{~s}^{-1}$ at $38 \mathrm{~km}$ (Figure 7). The analogous $\mathrm{Cl} / \mathrm{ClO}$ has a shorter chain length, which increases from 10 in the lower stratosphere to $10^{3}$ in the upper stratosphere and has a chair effectiveness which increases from $10^{2}$ molecules $\mathrm{cm}^{-3} \mathrm{~s}^{-1}$ at $12 \mathrm{~km}$ to $10^{10}$ molecules $\mathrm{cm}^{-3} \mathrm{~s}^{-1}$ at $38 \mathrm{~km}$. Consequently at $38 \mathrm{~km}$ the $\mathrm{NO} / \mathrm{NO}_{2}$ cycle is the main ozone loss cycle but above this the $\mathrm{Cl} / \mathrm{ClO}$ cycle is the main ozone loss cycle [Stolarski and Cicerone, 1974; Molina and Rowland, 1974].

\section{$\mathrm{BrO} / \mathrm{NO}_{2}$}

As was recently pointed out by Burkholder et al. [1995], if the products of $\mathrm{BrONO}_{2}$ photolysis are $\mathrm{Br}$ and $\mathrm{NO}_{3}$, then a very effective $\mathrm{BrONO}_{2}$ catalytic cycle can exist, namely 


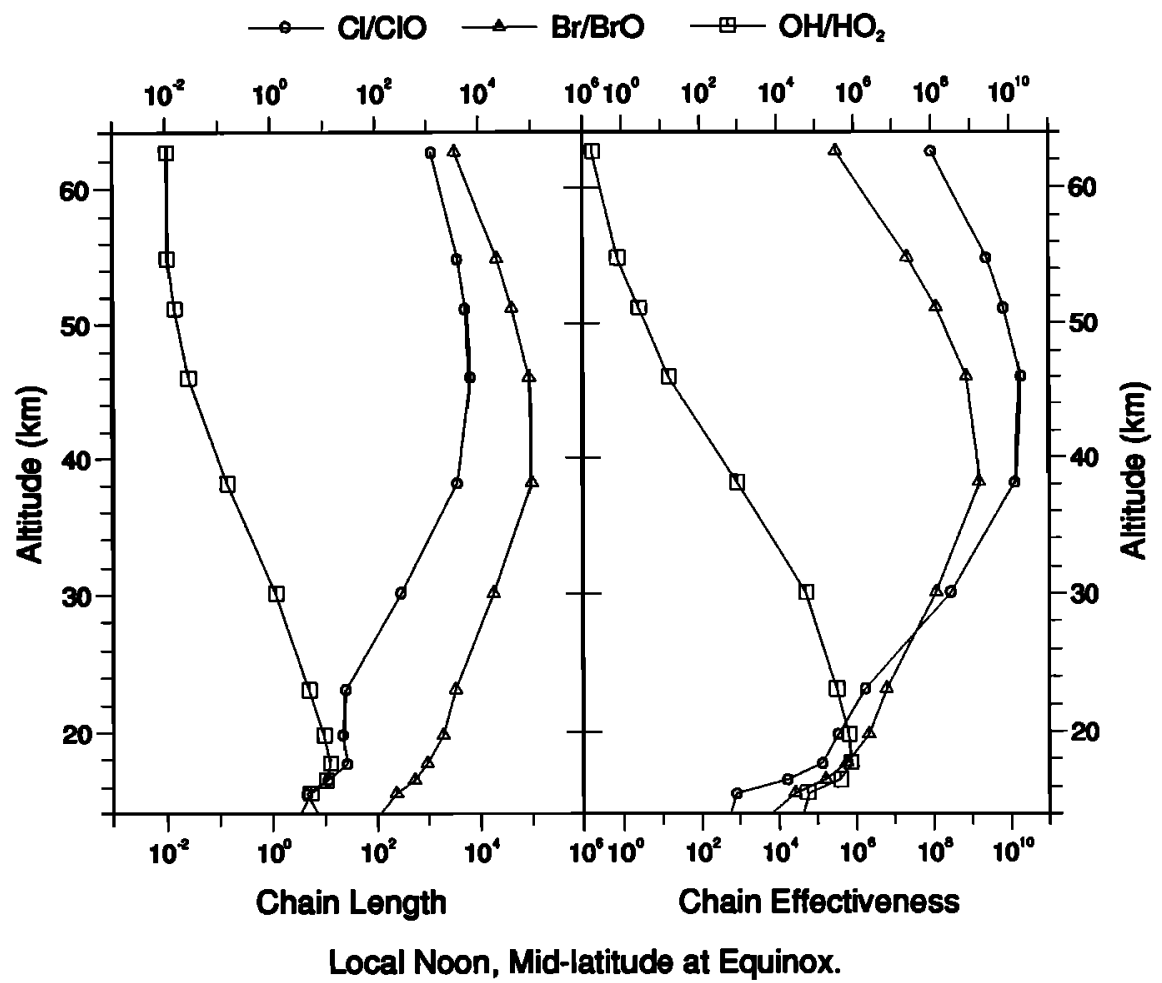

Figure 7. The calculated midlatitude chain length and chain effectiveness of various catalytic cycles for local noon at equinox.

\begin{tabular}{lllllll}
$\mathrm{BrO}$ & + & $\mathrm{NO}_{2}$ & $\mathrm{M}$ & $\mathrm{BrONO}_{2}$ & & \\
$\mathrm{BrONO}_{2}$ & + & $\mathrm{h} \nu$ & $\longrightarrow$ & $\mathrm{Br}$ & + & $\mathrm{NO}_{3}$ \\
$\mathrm{NO}_{3}$ & + & $\mathrm{h} \nu$ & $\longrightarrow$ & $\mathrm{NO}$ & + & $\mathrm{O}_{2}$ \\
$\mathrm{NO}$ & + & $\mathrm{O}_{3}$ & $\longrightarrow$ & $\mathrm{NO}_{2}$ & + & $\mathrm{O}_{2}$ \\
$\mathrm{Br}$ & + & $\mathrm{O}_{3}$ & $\longrightarrow$ & $\mathrm{BrO}^{2}$ & + & $\mathrm{O}_{2}$ \\
\hline $\mathrm{Net}$ & & $2 \mathrm{O}_{3}$ & $\longrightarrow$ & $3 \mathrm{O}_{2}$ & &
\end{tabular}

Depending on the conditions, the rate-limiting step of the cycle is the photolysis of $\mathrm{BrONO}_{2}$ or of $\mathrm{NO}_{3}$ to $\mathrm{NO}$. If it is assumed that the main $\mathrm{BrONO}_{2}$ photolysis products are $\mathrm{Br}$ and $\mathrm{NO}_{3}$ then the $\mathrm{BrO} / \mathrm{NO}_{2}$ cycle between about $15 \mathrm{~km}$ and $30 \mathrm{~km}$ has a chain length of more than $10^{3}$. The chain length decreases above $30 \mathrm{~km}$. The chain effectiveness is approximately $10^{7}$ molecules $\mathrm{cm}^{-3}$ $\mathrm{s}^{-1}$ between about 15 and $30 \mathrm{~km}$ (Figure 6). This result can be compared to the analolgous $\mathrm{ClO} / \mathrm{NO}_{2}$ cycle [Toumi et al., 1993] which has a chain length of about $10^{2}$ at the tropopause decreasing to only 3 at $40 \mathrm{~km}$, and a chain effectiveness of $10^{5}$ molecules $\mathrm{cm}^{-3}$ $\mathrm{s}^{-1}$ close to the tropopause decreasing to $10^{2}$ molecules $\mathrm{cm}^{-3} \mathrm{~s}^{-1}$ at $38 \mathrm{~km}$. This finding emphasizes the point made by Toumi et al. [1993] that the $\mathrm{ClO} / \mathrm{NO}_{2}$ cycle is only important for high levels of $\mathrm{ClONO}_{2}$. For typical levels of $\mathrm{BrONO}_{2}$ and $\mathrm{ClONO}{ }_{2}$ the $\mathrm{BrO} / \mathrm{NO}_{2}$ cycle is more effective at removing ozone than the analogous $\mathrm{ClO} / \mathrm{NO}_{2}$ cycle.

\section{Summary}

The current knowledge of gas phase bromine chemistry has been reviewed and two gas phase reactions not normally considered have been found to be important in the upper stratosphere. They are the reactions of $\mathrm{O}\left({ }^{3} \mathrm{P}\right)$ with $\mathrm{BrCl}$ and $\mathrm{HOBr}$ whose rates were measured by Clyne et al. [1976] and Nesbitt et al. [1995], respectively.

The effectiveness of the ozone catalytic loss cycles involving bromine has been quantified by considering their chain length and effectiveness. The chain effectiveness is a new variable defined as the chain length multiplied by the rate of the cycle's rate-limiting step. The chain effectiveness enables a fair comparison of different catalytic cycles involving species which have very different concentrations.

It is shown that in the low stratosphere the most effective ozone loss cycles are the $\mathrm{BrO} / \mathrm{HO}_{2}$ and $\mathrm{BrO} / \mathrm{ClO}$ cycles. Both catalytic cycles have long chain lengths of greater than $10^{3}$ and a chain effectiveness of between $10^{6}$ and $10^{8}$ molecules $\mathrm{cm}^{-3} \mathrm{~s}^{-1}$ in the lower stratosphere. The cycles are therefore effective ozone destruction cycles even when no PSCs are present.

If it is assumed that the main photolysis products of $\mathrm{BrONO}{ }_{2}$ are $\mathrm{Br}$ and $\mathrm{NO}_{3}$, then the $\mathrm{BrO} / \mathrm{NO}_{2}$ cycle between about $15 \mathrm{~km}$ and $30 \mathrm{~km}$ has a chain length of at least $10^{3}$. The chain length decreases above $30 \mathrm{~km}$. This cycle will only be effective for ozone loss if $\mathrm{BrONO}_{2}$ photolysis leads to the production of $\mathrm{Br}$ and $\mathrm{NO}_{3}$. This conclusion agrees with the recent findings of Burkholder et al. [1995] and can be compared to the anolgous $\mathrm{ClO} / \mathrm{NO}_{2}$ cycle [Toumi et al., 1993], which has a chain length of about $10^{2}$ at the tropopause decreasing to only 3 at $40 \mathrm{~km}$. 
Acknowledgments. The author wishes to thank $R$ A. Cox for very useful conversations and seminars, J. A. Pyle for his support, J. J. Orlando and J. B. Burkholder for making their results available to us before publication and D. Shallcross and J. Sessler for useful conversations. The Centre for Atmospheric Science is a joint initiative of the Department of Chemistry and the Department of Applied Mathematics and Theoretical Physics. This work forms part of the NERC U.K. Universities Global Atmospheric Modelling Programme.

\section{References}

Anderson, D. E., The troposphere to stratosphere radiation field at twilight: A spherical model, Planet. Space Sci., 31 (12), 1,517-1,523, 1983.

Atkinson, R., D. L. Baulch, R. A. Cox, R. F. Hampson, J,A. Kerr and J. Troe, Evaluated kinetic and photochemical data for atmospheric chemistry - Supplement IV, IUPAC subcommittee on gas kinetic data evaluation for atmospheric chemistry, J. Phys. Chem. Ref. Data, 21 (6), 1,125-1,568, 1992.

Baulch, D. L., J., Duxbury, S. J., Grant and D. C. Montague, Evaluated kinetic data for high temperature reactions. Volume 4 Homogeneous gas phase reactions of halogen and cyanide containing species, J. Phys. Chem. Ref. Data, 10, supplement 1,1-1, 1-721, 1981.

Berg, W. W., L. E. Heidt, W. Pollock, P. D. Sperry, R. J. Cicerone and E. S. Gladney, Brominated organic species in the Arctic atmosphere, Geophys. Res. Lett., 11, 429$432,1984$.

Burkholder, J. B., A. R. Ravishankara and S. Solomon, $\mathrm{UV} /$ visible and IR absorption cross sections of $\mathrm{BrONO}_{2}$, J. Geophys. Res., 100 (D8), 16,793-16,800, 1995.

Cicerone, R. J., L. E. Heidt and W. H. Pollock, Measurements of atmospheric methyl bromide and bromoform, $J$. Geophys. Res., 93, 3,745-3,749, 1988.

Clyne, M. A. A., P. B. Monkhouse and L. W. Townsend, Reactions of $\mathrm{O}\left({ }^{3} \mathrm{P}\right)$ atoms with halogens: The rate constants for the elementary reactions $\mathrm{O}\left({ }^{3} \mathrm{P}\right)+\mathrm{BrCl}, \mathrm{O}\left({ }^{3} \mathrm{P}\right)$ $+\mathrm{Br}_{2}$ and $\mathrm{O}\left({ }^{3} \mathrm{P}\right)+\mathrm{Cl}_{2}$, Int. J. Chem. Kinet., 8, 425, 1976.

Crutzen, P. J., The influence of nitrogen oxides on the atmospheric ozone content, Q. J.R. Meteorol. Soc., 96, 320, 1970.

Danis, F., F. Caralp, J. Massanet and R. Lesclaux, Kinetics of the reaction $\mathrm{BrO}+\mathrm{NO}_{2}+\mathrm{M} \rightarrow \mathrm{BrONO}_{2}+\mathrm{M}$ in the temperature range 263-343 K, Chem. Phys. Lett., 167 (5), 450-456, 1990 .

DeMore, W. B., et al., Chemical kinetics and photochemical data for use in stratospheric modeling, Evaluation Number 10, Jet Propul. Lab., Pasedena, Calif., Publ. 92-20, 1992.

DeMore, W. B., et al., Chemical kinetics and photochemical data for use in stratospheric modeling, Evaluation Number 10, Jet Propul. Lab., Pasedena, Calif., Publication 94-26, 1994.

Fabian, P, R. Borchers and K. Kourtidis, Brominecontaining source gases during EASOE, Geophys. Res. Lett., 21 (13), 1,219-1,222, 1994.

Fan, S. M. and D. J. Jacob, Surface ozone depletion in Arctic spring sustained by bromine reactions on aerosols, Nature, 359 (6395), 522-524, 1992

Fisher, M. and D. J. Lary, Lagrangian four dimensional variational assimilation of chemical species, Q. J. R. Meteorol. Soc., 121 (527), 1,681-1,704, 1995.

Garcia, R. R. and S. Solomon, A new numerical-model of the middle atmosphere: 2 - Ozone and related species, $J$. Geophys. Res., 99 (D6), 12937-12951, 1994.
Gear, C. W., Numerical initial value problems in ordinary differential equations, Prentice-Hall, Englewood Cliffs N.J., chap. 9, 1971.

Hanson, D. R. and A. R. Ravishankara, Heterogeneous chemistry of bromine species in sulphuric acid under stratospheric conditions, Geophys. Res. Lett., 22, 385-388, 1995.

Heneghan, S. P. and S. W., Benson, Kinetic study of the reactions of $\mathrm{Cl}$ and $\mathrm{Br}$ with $\mathrm{H}_{2} \mathrm{O}_{2}$, Int. J. Chem. Kinet., 15, 1,311-1,319, 1983.

Johnston, H. S., Reduction of stratospheric ozone by nitrogen oxide catalysts from supersonic transport exhausts, Science, 179, 517-522, 1971.

Kaye, J. A., S. A. Penkett and F. M., Ormond, Report on concentrations lifetimes and trends of CFCs halons and related species, NASA Ref. pub. 1339, 1994.

Lary, D. J. and J. A. Pyle, Diffuse radiation, twilight and photochemistry - I, J. Atmos. Chem., 19, 373-392, 1992.

Lary, D. J. and J. A. Pyle, Diffuse radiation, twilight and photochemistry - II, J. Atmos. Chem., 19, 393-406, 1992.

Lary, D. J., M. P., Chipperfield and R. Toumi, The potential impact of the reaction $\mathrm{OH}+\mathrm{ClO} \rightarrow \mathrm{HCl}+\mathrm{O}_{2}$ on polar ozone photochemistry, J. Atmos. Chem., 21 (1), 61-79, 1995.

Lary, D. J., M. P., Chipperfield, R. Toumi and T. M. Lenton, Heterogeneous atmospheric bromine chemistry, J. Geophys. Res., this issue.

Leu, M. T., Upper limits for the rate constant for the reaction $\mathrm{Br}+\mathrm{H}_{2} \mathrm{O}_{2}$, Chem. Phys. Lett., 69, 37-39, 1980.

McElroy, M. B., R. J. Salawitch, S. C. Wofsy, and J. A. Logan, , Reductions of antarctic ozone due to synergistic interactions of chlorine and bromine, Nature, 321 (6072), 759-762, 1986.

Meier, R. R., D. E. Anderson and M. Nicolet, The radiation field in the troposphere and stratosphere from $240 \mathrm{~nm}$ to 1000 nm: General analysis, Planet. Space Sci., 30 (9), 923-933, 1982.

Mellouki, A., R. K., Talukdar and C. J. Howard, Kinetics of the reactions of $\mathrm{HBr}$ with $\mathrm{O}_{3}$ and $\mathrm{HO}_{2}$ : The yield of $\mathrm{HBr}$ from $\mathrm{HO}_{2}+\mathrm{BrO}, J$. Geophys. Res., 99 (D11), 22,949$22,954,1994$.

Molina, M. J. and F. S. Rowland, Stratospheric sink for chlorofluoromethanes: Chlorine atom catalysed destruction of ozone, Nature, 249, 810-814, 1974.

Nicolet, M., R. R., Meier and D. E. Anderson, The radiation field in the troposphere and stratosphere from $240 \mathrm{~nm}$ to 1000 nm: Numerical analysis, Planet. Space Sci., 30 (9), 935-983, 1982.

Nesbitt, F. L, P. S., Monks, W. A., Wayne, L. J, Stief and R. Toumi, The reaction of $O\left({ }^{3} \mathrm{P}\right)+\mathrm{HOBr}$ : Temperature dependence of the rate constant and importance of the reaction as an $\mathrm{HOBr}$ loss process, Geophys. Res. Lett., 22 (7), 827-830, 1995.

Orlando, J. J. and J. B. Burkholder, Gas phase UV/visible absorption spectra of $\mathrm{HOBr}$ and $\mathrm{Br}_{2} \mathrm{O}, J$. Phys. Chem., 99 (4), 1,143-1,150, 1995.

Posey, J., J., Sherwell and M. Kaufman, Kinetics of the reactions of atomic bromine with $\mathrm{HO}_{2}$ and $\mathrm{H}_{2} \mathrm{O}_{2}$, Chemical Physics Letters, $7 \gamma$ (3), 476-479, 1981.

Poulet, G., M., Pirre, F., Maguin, R., Ramaroson, G., Lebras, The Role of the $\mathrm{BrO}+\mathrm{HO}_{2}$ reaction in the stratospheric chemistry of bromine, Geophys. Res. Lett., 19 (23), 2,305-2,308, 1992

Penkett, S. A., B. M. R., Jones, M. J., Rycroft and D. A., Simmons, An interhemispheric comparison of the concentrations of bromine compounds in the atmosphere, $\mathrm{Na}$ ture, 318 (6046), 550-553, 1985.

Press, W. H., S. A. Teukolsky, W. T. Vetterling and B. P. Flannery, Numerical recipes in fortran - The art of scientific computing, 2nd. ed., Cambridge Univ. Press,, New York, 1992. 
Rasmussen, R. A. and M. A. K.Khalil, Gaseous bromine in the Arctic and Arctic haze, Geophys. Res. Lett., 11 (5), 433-436, 1984.

Reeves, C. E. and S. A.Penkett, An estimate of the anthropogenic contribution to methyl bromide, Geophys. Res. Lett., 20 (15), 1563-1566, 1993.

Seery, D. J. and D. Britton, The continuous absorption spectra of chlorine, bromine, bromine chloride, iodine chloride and iodine bromide, J. Phys. Chem., 68, 2,263-2,266, 1964.

Singh, H. B., L. J. Salas and R. E. Stiles, Methyl halides in and over the Eastern Pacific $\left(40^{\circ} \mathrm{N}-32^{\circ} \mathrm{S}\right), J$. Geophys. Res., 88, 3,684-3,690, 1983.

Spencer, J. E. and F. S. Rowland, Bromine nitrate and its stratospheric significance, J. Phys. Chem., 82, 7-10, 1978.

Stoer, J. and R. Bulirsch, Introduction to numerical analysis, chap. 7, Springer-Verlag, New York, 1980.

Stolarski, R. S. and R. J. Cicerone, Stratospheric chlorine A possible sink for ozone, Canadian J. Chem., 52, 1,6101,615, 1974.

Thorn, R. P., E. P. Dayin and P. H. Wine, Kinetics of the $\mathrm{BrO}+\mathrm{NO}_{2}$ association reaction, temperature and pressure dependence in the falloff regime, Int. J. Chem. Kinet., 25 (7), 521-537, 1993.
Toohey, D. W., W. H. Brune and J. G. Anderson, Mechanism and kinetics of $\mathrm{Br}+\mathrm{HO}_{2} \rightarrow \mathrm{HBr}+\mathrm{O}_{2}$ and $\mathrm{Br}+$ $\mathrm{H}_{2} \mathrm{O}_{2} \rightarrow$ products over the temperature range 260-390 K, J. Phys. Chem., 91, 1,215-1,222, 1987.

Toumi, R., R. L. Jones and J. A. Pyle, Stratospheric ozone depletion by $\mathrm{ClONO}_{2}$ photolysis, Nature, 365, 37-39, 1993.

Yung, Y. L., J. P., Pinto, R. T., Watson and S. P. Sander, Atmospheric bromine and ozone perturbations in the lower stratosphere, J. Atmos. Sci., 37, 339-353, 1980.

World Meteorological Organisation, Scientific assessment of stratospheric ozone: 1988, WMO Global Ozone Research and Monitoring Project, Rep. 20, 1990.

World Meteorological Organisation, Scientific assessment of stratospheric ozone: 1991, WMO Global Ozone Research and Monitoring Project, Rep. 25, 1992.

D. J. Lary, Centre for Atmospheric Science, Department of Chemistry, Cambridge University, Lensfield Road, Cambridge, CB2 1EW, U.K. (email:david@atm.cm.cam.ac.uk)

(Received March 9, 1995; revised June 29, 1995; accepted June 29, 1995.) 